DOI: 10.46340/eppd.2021.8.3.17

\author{
Serhii Mishyn \\ ORCID ID: https://orcid.org/0000-0002-1055-1629 \\ National University "Odesa Law Academy", Ukraine
}

\title{
EFFICIENCY OF ACTIVITIES \\ OF REGIONAL AUTHORITIES \\ AND LOCAL SELF-GOVERNMENT
}

\author{
Сергій Мішин \\ Національний Університет "Одеська юридична академія», Україна
}

\section{ЕФЕКТИВНІСТЬ ДІЯЛЬНОСТІ \\ ОРГАНІВ РЕГІОНАЛЬНОЇ ВЛАДИ \\ ТА МІСЦЕВОГО САМОВРЯДУВАННЯ}

The problem of improving the efficiency of regional authorities and local self-government in Ukraine has always been relevant. And today this problem remains one of the most acute, despite the long process of reforming this institution of public power. The article defines the criteria for the effectiveness of regional authorities in achieving the level and dynamics of indicators of socioeconomic development of regions. The definition of efficiency criteria creates the preconditions for a systematic study of effectiveness, decision-making and measures to further improve the work of local governments, as well as the encouragement of municipalities that have achieved the best values. Numerous developments of domestic and foreign scientists are studied on the typology, nature and essence of efficiency in general and in direct connection with the activities of regional authorities and local governments. In this regard, the relationship between the concepts of "efficiency" and "productivity" is analyzed. To determine the effectiveness of regional authorities, the author considers it necessary to design the concept of efficiency in space and the results of its activities, to determine the value aspects for its evaluation. The defining elements of effective organizational and managerial activities are the nature of the relationship, the driving forces and decision-making processes. The author traces the dependence of the effectiveness of any type of social activity, including executive and administrative activities of the authorities, on the forms and methods of achieving this goal. In addition, the author insists on the need to assess not only the internal activities of regional authorities and local governments, but also the activities in connection with their external manifestation, in the unity of social and political aspects.

Keywords: local self-government, territorial authorities, regional authorities, efficiency, local self-government reform.

Постановка проблеми. Сучасний світ характеризується глобальними змінами як в політичному, так і в соціально-економічному житті та багато в чому визначається результативністю реформ, які направлені на підвищення ефективності функціонування різних інститутів суспільства. Реформи, що проводяться в нашій країні, спрямовані на створення оптимальної та ефективної системи державного управління, тому що тільки ефективна державна влада здатна створити умови для підвищення рівня та якості життя населення. Слід відзначити, що підвищення ефективності діяльності державних органів управління $\epsilon$ складним, комплексним завданням, яке вимагає концентрації зусиль багатьох структур суспільства, відкритості влади до змін, готовності населення до діалогу з владою. Все це вимагає переосмислення значення ролі та функцій держави, сутності взаємовідносин суспільства і держави.

Аналіз останніх досліджень і публікацій. Питанням діяльності та оцінювання органів регіональної влади та місцевого самоврядування в науковій літературі присвячено досить багато досліджень, зокрема це публікації А. Пехник, А. Кройтора, В. Вакуленка, М. Василенка, О. Галацан, В. Кравченка, В. Дзюндзюка, Р. Войтовича, В. Карпенка, В. Куйбіди, Н. Зіновчука, Я. Малика, М. Пухтинського, Ю. Шарова та інших. 
Мета статті: визначити критерії та фактори ефективності діяльності органів регіональної влади та місцевого самоврядування.

Виклад основного матеріалу. Підвищення ефективності діяльності органів державного управління являє собою цілий комплекс складних взаємопов'язаних процесів, що включають в себе не тільки організаційні та структурні зміни в системі управління, а й вдосконалення механізмів здійснення повноважень і функцій державного управління. При цьому вдосконалення системи державного управління має супроводжуватися не тільки зміцненням владних повноважень, а й одночасним дотриманням громадських інтересів, забезпеченням прозорості діяльності органів і установ державної влади, а також протидією корупції.

Створення дієвих засобів практичного дослідження ефективності органів регіональної влади має базуватись на здобутках різних наукових дисциплін i, насамперед державного управління, яка вивчає формування, організацію, функціонування, оцінку результативності та ефективності державного управління економічними і соціальними процесами в суспільстві.

Ефект (від лат. effectus) означає виконання, дію. Відповідно, ефективність - «це результат, наслідок якихось причин, сил, дій. Звідси найбільш поширене розуміння терміна ефективність пов'язане 3 тим, що приводить до потрібних результатів, тобто ефективних ознак» ${ }^{1}$. Інколи ефективність визначають як «узгодженість результату з метою». Так, Е.Савас вважає, що є «два види ефективності: дієвість (efficiency), яку можна підрахувати кількісно і вивести коефіцієнт корисної дії, та ефективність (effectiveness), що має якісний характер і $є$ оцінним поняттям» ${ }^{2}$.

До кінця XIX ст. у зарубіжній науковій практиці обидва види ефективності використовувались як синоніми. 3 початку XX ст. термін «efficiency» набув іншого значення та трактувався як співвідношення між внеском (вхідними ресурсами) та результатом, зусиллями й результатом, витратами та доходами, витратами та задоволенням. Обидва терміни можуть бути перекладені українською мовою як «ефективність». Ці два види ефективності Е.Савас поклав в основу відокремлення політики від адміністрування. Їх відмінність формується на рівні діяльності менеджера ділової (промислової) організації. На його переконання, управлінська діяльність менеджера полягає в отриманні оптимального результату від наявних у його розпорядженні матеріальних і людських ресурсів. «Efficiency»- робити краще те, що вже робиться, а ефективність передбачає пошук можливостей отримати додаткові прибутки, створити нові ринки і постійно змінювати економічні характеристики товарів ${ }^{3}$.

У широкому розумінні, на думку Г.Саймона, «діяти ефективно означає використовувати найкоротший спосіб і найдешевші засоби для досягнення бажаних цілей» ${ }^{4}$. Термін «efficiency» вказує на те, що рухає людьми, чим вони керуються у своїх діях, і пов'язується значною мірою 3 психологічними факторами поведінки людей. Ефективність (efficiency) пов'язана із задоволенням індивідуальних мотивів і за своїм характером є особистою. Г.Атаманчук у своїх дослідженнях виділяє різні види ефектів, визначає критерії соціальної ефективності, зокрема звертає увагу на два аспекти, що впливають на зміст ефекту, а саме: «різницю між результатами і затратами, яка свідчить про вигоду, яка створена людськими зусиллями; здатність цієї вигоди задовольняти реальні життєві потреби людей, суспільства» ${ }^{5}$.

Види ефектів дослідник класифікує за схемою:

1) «продуктивний ефект (застосовувався за централізованої планової економіки, коли організаціям надсилались номенклатурно-натуральні показники, що підлягали обов'язковому виконанню), який пов'язаний із державними інституціями, що виробляють конкретний продукт чи надають соціальну послугу. Він вимірюється співвідношенням одержаних результатів у процесі виробництва продукту (послуги) та затрат на його виготовлення, пов'язаними з внутрішньою організацією праці, $\epsilon$ технологічним і вимірюється за нормативно-вартісними затратними показниками» ${ }^{6}$;

2) «економічний ефект, який свідчить про потреби щодо того чи іншого продукту (послуги), про співвідношення попиту і пропозиції на нього в суспільстві. Внаслідок реалізації продукту

\footnotetext{
${ }^{1}$ Кхол, Й. (1975). Эффективность управленческих решений. Москва, 55.

${ }^{2}$ Савас, Э. (1972). Приватизация - ключ к рынку. Москва, 35.

${ }^{3}$ Там само.

${ }^{4}$ Саймон, Г. (2001). Адміністративна поведінка: дослідження процесів прийняття рішень в організаціях, щчо виконують адміністративні функиії. Київ, 12.

${ }_{5}^{5}$ Атаманчук, Г. (2000). Государственное управление (организациионо-функциональные вопросы). Москва, 248.

${ }^{6}$ Там само, 249.
} 
виробник не лише повертає затрачені ресурси, але й одержує прибуток, завдяки цьому економіка стає динамічною і саморегульованою»';

3) «соціальний ефект, який розглядається як сукупний загальний результат, що отримує суспільство як у процесі виробництва продукту (послуги), так і в процесі споживання матеріальних, соціальних і духовних цінностей. Він свідчить про актуальність, раціональність і ефективність будьякої праці та найбільш повно висвітлює працю і талант, знання й досвід, уміння та совість людей» ${ }^{2}$.

На думку Г.Атаманчук, «діяльність органів регіональної влади повинна базуватися насамперед на соціальних ефектах, оскільки саме держава несе відповідальність за нього, законодавчо визначає і захищає права та свободи людей, відслідковує їх раціональне та ефективне використання», а «соціальний ефект, можливий лише за раціональної організації суб'єктів управління, насамперед, органів державної влади і органів місцевого самоврядування, оптимального функціонування об'єктів, якими управляють» ${ }^{3}$.

Деякі вчені визначають «ефективність органів регіональної влади як співвідношення результатів діяльності із задекларованими цілями» (наприклад ${ }^{4}$ ). В.Цвєтков у своїх дослідженнях виділяє два поняття: «економічна ефективність і цільова ефективність. Економічна ефективність управління визначається як результат діяльності системи управління, що забезпечує досягнення мети, поставленої перед об’єктом управління, за найменших витрат, а цільова ефективність визначається як узгодженість результату 3 метою» ${ }^{5}$. На додаток до цих категорій В.Цвєтков виділяє поняття «організаційна ефективність» і трактує його як «оптимальну форму взаємозв'язків елементів системи, яка робить її найбільш ефективною в досягненні поставленої мети. Ця модель свідчить про те, що хоча певні функціональні зв'язки можуть і задовольнити вимоги організації, однак деякі з них ефективніші ніж інші» ${ }^{6}$.

Ефективність органів регіональної влади В.Цвєтков пов'язує із «громадською свідомістю, 3 правовим становищем людини в суспільстві» виходячи з гіпотези, що: «ефективність державного управління - це людська специфіка управління, що здійснюється людиною i для людини» ${ }^{7}$. Б.Гаврилишин вважає, що «ефективність влади - це, насамперед, іії прийнятність (аспект соціальної ефективності). Йдеться про те, що суспільство не байдуже до того, як здійснюється управління, воно зацікавлене в його високій якості» ${ }^{8}$.

А.Мельник виділяє три рівні ефективності: «загальна соціальна ефективність (рівень держави та усієї системи державного управління), спеціальна соціальна ефективність (ефективність функціонування суб'єктів державного управління), конкретна соціальна ефективність (ефективність діяльності управлінських органів і посадових осіб)»" .

М.Лесечко також пов'язує «ефективність із співвідношенням результатів і визначає іï як нормований до затрат ресурсів результат дії або діяльності системи на певному інтервалі часу (відношення ефекту до затраченого ресурсу, різниця між ними, ефект за обмеженого ресурсу)» ${ }^{10}$. Вчений досліджує два основних напрями ефективності: «телеологічний та природно-науковий» ${ }^{11}$. Відповідно до першого напряму під ефективністю системи розуміється «кількісно виражений позитивний вплив, який система вносить у функціонування надсистеми, а в контексті другого передбачається введення фізично вимірюваного критерію ефективності на підставі постулату про фізичну природу зв'язків між системою і над системою» ${ }^{12}$.

Н.Нижник у своїх дослідженнях виділяє три основних підходи до розуміння ефективності державного управління: «модель оцінки ефективності за схемою- ресурсне забезпечення

\footnotetext{
${ }^{1}$ Там само, 250.

${ }^{2}$ Там само.

${ }^{3}$ Там само, 252.

${ }^{4}$ Бабінова, О. (2007). Критерії оцінки ефективності діяльності органів місцевого самоврядування: світовий досвід та Україна. Регіональна політика та місцеве самоврядування. Стратегічні пріоритети, 2 (3), 80.

${ }^{5}$ Цвєтков, В. (1996). Державне управління: основні фактори ефективності (політико-правовий аспект). Харків, 37.

6 Там само, 40.

7 Там само, 50.

${ }^{8}$ Гаврилишин, Б. (2009). До ефективних суспільств: Дороговкази в майбутнє: доповідь Римському Клубові. Київ, 121.

${ }^{9}$ Мельник, А. (2009). Державне управління. Київ, 45.

10 Лесечко, М. (2002). Основи системного підходу: теорія, методологія, практика. Львів, 221.

${ }^{11}$ Там само, 222.

12 Там само.
} 
діяльності - затрати - результат, яка аналогічна моделі: внесок - продукт; модель довготермінової організації Р.Лайкерта, за якою ефективність визначають три групи факторів: внутрішньоорганізаційні чинники (змінні), які перебувають під контролем організації: формальна структура організації, економічна стратегія і соціальна політика, професійно-кваліфікаційний склад персоналу тощо; проміжні змінні, що представляють людські ресурси організації: організаційний клімат, ставлення до праці, навички людей, рівень довіри до керівництва, традиції, методи прийняття рішень, способи стимулювання і мотивації діяльності; результативні (наслідкові) змінні, які виражають остаточний результат зусиль - зростання і падіння прибутку, зростання чи зниження продуктивності праці, ступінь задоволення потреб тощо; модель захисту збалансованих інтересів суспільства і держави, що проявляється в успішному розв'язанні проблеми оптимального захисту інтересів держави, населення, соціальних груп та окремого громадянина. I ефективність буде забезпечена лише у разі взаємодії трьох складових: громадян, суспільства та держави» ${ }^{1}$.

А.Чемерис запропонував модель «групової дієвості органів державної влади як передумови ефективного управління» ${ }^{2}$. На його думку, «дієвість подібна до ефективності, $є$ їі передумовою i складається з таких елементів: групова соціальна компетенція - здатність організацій мобілізувати на внутрішні проблеми (держави, регіону, громади) всі ресурси, досягти виконання соціальних цілей; групова фахова компетенція - набір фахових знань персоналу організацій, необхідних для вирішення соціально-економічних, політичних, екологічних, культурологічних, правових та інших проблем у межах поставлених перед організацією цілей; групова методична компетенція - знання керівництвом і персоналом організації наукових методів управління, сучасних технологій прийняття i реалізації управлінських рішень, володіння найрізноманітнішими допоміжними засобами для розв'язання проблем; зовнішнє середовище - система природних, економічних, соціальних, правових, екологічних, культурологічних та інших чинників, що впливають на організацію і щодо яких організація не має готових рішень або суттєвих впливів; внутрішнє середовище організаціївнутрішні економічні та матеріально-технічні ресурси, соціальні, правові, організаційні, технологічні та інформаційні складові організації, традиції, цілі, мікроклімат, ціннісні орієнтири, рівень організованості, система мотивацій тощо» ${ }^{3}$.

Американські вчені акцентують свою увагу на терміні «продуктивність», який також використовують у сфері публічного адміністрування і під яким розуміють співвідношення між отриманим результатом i витраченими ресурсами. Тобто продуктивність, як і ефективність, виражається співвідношенням «затрати - випуск». Між тим продуктивність передбачає максимізацію органом влади своїх цілей за мінімальних витрат ресурсів. Б.Мільнер вважає, що «ефективність та продуктивність взаємопов'язані між собою, але водночас між ними існують певні відмінності. Продуктивність $€$ ширшим поняттям, до якого належить визначення ефективності ${ }^{4}$.

Шведський досвід оцінки діяльності органів державного управління демонструє модель (яка отримала назву аудит адміністративної діяльності), основану на парадигмі «внесок - продукт», яка включає три складові: - «економічність (есоnomy) - тобто орієнтація на найменші витрати, зокрема мінімізація вартості ресурсів, спрямованих на діяльність із досягнення визначеної якості послуги з урахуванням законності використання державних фондів. Тобто встановлюється відповідність використання ресурсів потребам, належність кількості ресурсів відповідній якості у визначений час, у необхідному місці, за розумну ціну; - ефективність (efficiency) - співвідношення між продуктом у вигляді наданих товарів (послуг) та ресурсами, використаними на їх створення. Аналізується технологія та методи роботи, співпраця підрозділів, засоби заохочення працівників до скорочення витрат робочого часу. Встановлюється практика найкращого досвіду, який орієнтовано на отримання максимуму продукту в термінах, кількості та якості, які відповідають внеску і способам діяльності; результативність (effectiveness) - ступінь відповідності досягнутих результатів поставленій меті нормі». У процесі аналізу результативності оцінюється «вчасність досягнення мети, ступінь задоволення людей відповідною програмою» 5 .

\footnotetext{
${ }^{1}$ Нижник, Н. (2000). До проблеми ефективності державного управління в Україні. Підвищення ефективності державного управління: стан, перспективи та світовий досвід: збірник наукових праць, Київ, 9.

2 Чемерис, А. (2001). Дієвість органів державного управління та органів місцевого самоврядування. Вісник державної служби України, 1, 54.

${ }^{3}$ Там само, 55.

${ }^{4}$ Мильнер, Б. (2000). Теория организацฺии. Москва, 124.

${ }^{5}$ Бабінова, О. (2007). Критерії оцінки ефективності діяльності органів місцевого самоврядування: світовий досвід та Україна. Регіональна політика та місцеве самоврядування. Стратегічні пріоритети, 2 (3), 79.
} 
Таким чином, різні дослідники пропонують досить широкий спектр критеріїв оцінки діяльності регіональної влади та кількісних параметрів. Для визначення ефективності органів регіональної влади необхідно поняття ефективності спроектувати на простір і результати його діяльності, визначити ціннісні аспекти для її оцінки.

Ціннісні аспекти встановлюють особливості проведення оцінки ефективності і зміст їі контенту в спектрі його впливу на суспільство, особу чи сферу функціонального застосування. Комплекс ціннісних орієнтацій для проведення оцінки може включати визначення: суб'єкта оцінки, зацікавленого в результатах аналізу діяльності органу публічної влади: споживач, співробітник, партнер, контролюючий орган, рейтингове агентство і т. ін.; локального предмета оцінки: функції, послуги чи іншого аспекту адміністративно-управлінської діяльності; рівня аналізу якостей, послуг чи продуктів діяльності; індикаторів та показників, які використовуються у сфері чи галузі, для регулювання результативності; цільової спрямованості дослідження (розпізнати досягнення, слабкі та сильні сторони, аналіз зайвих витрат, виокремлення найкращого досвіду); часового інтервалу оцінки (для забезпечення гарантій достовірності порівняльних оцінок чи пошуку довгострокових тенденцій, періодичності максимумів і мінімумів навантаження на управлінську структуру); меж чи стандартів для встановлення достатності діяльності (стандарт достатності ефективності, твінінгпартнери, цільові завдання й обмеження).

Критерії ефективності покликані орієнтувати органи регіональної влади на задоволення повсякденних суспільних потреб та визначати якість і результативність їх вирішення. Визначальними елементами ефективної організаційно-управлінської діяльності є характер взаємовідносин, рушійні сили та процеси прийняття рішень. Активно впливають на зростання ефективності роботи апарату управління систематичний контроль за якістю і термінами виконання роботи, використання науково обгрунтованих нормативів затрат праці на здійснення конкретних управлінських операцій і норм чисельності управлінських працівників, ефективне використання управлінської техніки, сприйнятливість в опануванні передових прийомів роботи.

Загалом, ефективність будь-якого виду соціальної діяльності залежить від форм і методів досягнення поставленої мети, що особливо проявляється у виконавчо-розпорядчій діяльності, в роботі апарату тощо, рівень професійної культури якого $\epsilon$ важливим критерієм загальної культури суспільства та впливає на соціально-правове становище в ньому особистості. Таким чином, підвищення ефективності і якості роботи всіх ланок органів публічної влади, удосконалення їх структури, організації і практичної діяльності є визначальним елементом загального процесу поліпшення якісних характеристик сучасного суспільного розвитку країни.

Органи регіональної влади не можна оцінювати 3 погляду лише на їх внутрішню діяльність. Необхідно робити акцент на тих змінах, які відбуваються внаслідок діяльності органу в зовнішньому середовищі, об'єкті управління, характері і ступені цих змін. Найскладніше - це виявити вплив відомчої роботи на суспільство, відносини, що складаються в ньому, і визначити результат цієї роботи. Крім того, не можна забувати, що будь-яка діяльність завжди має дві протилежні складові і може продукувати одночасно як позитивні, так і негативні результати.

Соціальна ефективність органів регіональної влади полягає, по суті, в одному - у встановленні чітких, дієвих механізмів суспільної координації. У загальному ключі, в масштабах країни, ії можна встановити на основі аналізу соціальних індикаторів. Прикладами соціальної неефективності є такі поняття, як нерівноправ'я, збереження безробіття, бідності, обмеження доступу до вертикальної мобільності, освіти, послуг охорони здоров'я (через матеріальне положення).

Політична ефективність пов'язана з такими явищами, як вертикаль влади, розподіл владних повноважень, легітимність, рівень демократизації суспільства і багато що інше. Економічна ефективність виражається як у кількісних показниках виробництва i розподілу національного багатства, так і мірою відкритості економіки і свободи підприємництва та торгівлі. Слід також розрізняти ефективність проведення державних рішень ужиття. Питання в тому, наскільки ці рішення (ті ж закони) дотримуються в суспільстві, і які наслідки, крім задуманих, мають. Вона відрізняється від виконавської ефективності тим, що виконавцями цих рішень $є$ не безпосередньо підлеглі особи, а народ у цілому.

У роботі П.Друкера «Ефективний керівник», де він проводить чітке розділення між термінами результативність, продуктивність (efficiency - те, що називають виконавською ефективністю) i ефективність (effectiveness), стосовно продуктивності зазначається, що «працівник фізичної праці повинен бути здатний правильно виконувати поставлені перед ним завдання, але його не стосується 
сама їх адекватність. Діяльність працівника фізичної праці завжди можна оцінити по кількості і якості, що легко піддається визначенню й обліку продукції, як, наприклад, взуття». Таким чином, П.Друкер вказує на «напрями застосування як критеріїв оцінювання ефективності персональних показників роботи працівників органу управління» ${ }^{1}$.

За останнє сторіччя людство навчилося визначати результативність і якість фізичної праці. У випадку з ефективністю працівник відтворює знання, ідеї й інформацію. Сама по собі «продукція не має сенсу, вона набуває значення, коли хтось скористається нею з тим, щоб досягти конкретних результатів» ${ }^{2}$. Таким чином, працівник, який займається інтелектуальною, творчою діяльністю, повинен робити щось таке, чого працівникові фізичної праці робити не потрібно. Він зобов'язаний додавати роботі ефективність.

Відмінності у визначенні предмета аналізу тісно пов'язані з різними підходами до моделювання й оцінки ефективності управління інституцією. Так, можна виділити дві моделі аналізу. Механістична модель розглядає орган як механізм, що $є$ комбінацією основних виробничих чинників: засобів створення продуктів діяльності виробництва, робочої сили, ресурсів, тобто як машину для реалізації цілей iї творців. Велике значення при цьому надається аналізу зв'язків і залежності різних чинників виробництва. А завдання менеджменту за такого підходу полягає, перш за все, в тому, щоб найкращим чином згрупувати всі частини системи i, тим самим, досягти максимальної ефективності в досягненні цілей.

Гуманістична модель представляє орган як колектив людей, які виконують роботу на принципах поділу і кооперації праці, при цьому найважливішим чинником продуктивності $€$ людина. Елементами моделі є такі складові, як увага до тих, хто працює, їх мотивація, комунікації, участь в ухваленні рішень. Завдання керівників полягають у регулюванні відносин між працівниками, координації процесів під час виконання конкретних завдань і планів діяльності шляхом особистого і безпосереднього впливу на співробітників. Критерієм ефективності органів регіональної влади $€$ підвищення продуктивності праці за рахунок удосконалення людських ресурсів, тобто вважається, що якщо всі внутрішні процеси, пов'язані з персоналом, управляються належним чином, то в інституції не виникає проблем із досягненням намічених цілей.

Вплив органів державної влади та органів місцевого самоврядування на рівень та темпи економічного розвитку регіонів полягає в першу чергу в створенні умов і стимулів для залучення інвестицій, в підтримці підприємницької активності та бізнесу, у формуванні необхідної для цього інфраструктури, створення умов для зниження безробіття та адміністративних бар'єрів. Найважливішим елементом економічної політики на сучасному етапі $\epsilon$ розвиток людського потенціалу в першу чергу, становлення на регіональному рівні ефективних систем охорони здоров'я та освіти, особливо професійної, формування комфортного середовища проживання, здатної утримувати та залучати до регіонів кваліфіковані кадри. Основне завдання влади всіх рівнівпідвищувати результативність своїх дій та ефективність використання ресурсів.

Вирішення проблеми підвищення ефективності регіональних органів влади можливо тільки шляхом впровадження сучасних фінансово-економічних моделей управління. Виділення коштів має бути обумовлено проведенням інституційних перетворень в сферах державного управління та підвищення інвестиційної привабливості України.

Основним завданням органів виконавчої влади $\epsilon$ формування ефективних регіональних систем управління. Досягнення даного завдання можливе, перш за все, шляхом введення сучасних методів управління, спрямованих на підвищення ефективності використання наявних ресурсів, а саме: зниження неефективних поточних витрат; підвищення заробітної плати працівників бюджетної сфери; підвищення доступності та якості послуг, які надаються; збільшення витрат на основні засоби 3 метою створення необхідної інфраструктури.

Впровадження сучасних методів управління повинно бути визнано як загальнодержавне завдання, що реалізується спільно з регіональними та муніципальними органами влади.

3 метою стимулювання впровадження ефективних методів управління на регіональному рівні необхідно забезпечити координацію оцінки ефективності діяльності регіональних органів влади 3 галузевими системами оцінки органів влади, в тому числі шляхом інтеграції галузевих рейтингів i оцінок до єдиної системи; проведення оцінки ефективності діяльності з заохоченням органів

\footnotetext{
${ }^{1}$ Друкер, П. (2000). Задачи менеджмента в ХХІ веке. Москва, 68.

2 Розпутенко, І., Пухкал, О., Брайченко, О. (2005). Ефективність державного управління та управлінських кадрів в умовах змін. Київ, 67.
} 
місцевого самоуправління, які досягли найкращих значень показників ефективності; поширення кращої практики регіонального управління, включаючи успішне проведення інституційних перетворень і поліпшення якості життя населення.

Для поліпшення показників слід реалізувати перелік заходів щодо підвищення результативності діяльності органів місцевого самоврядування, в тому числі щодо зниження неефективних витрат, а також по виявленню внутрішніх ресурсів (фінансових, матеріально-технічних, кадрових та інших) для підвищення якості та обсягу наданих населенню послуг і збільшення заробітної плати працівників бюджетної сфери.

Існують і інші фактори, що обмежують розвиток місцевого самоврядування в тому чи іншому його значенні. Перш за все мова йде про відносини між владою і суспільством, про відмінності, які існують в розумінні основних демократичних цінностей та інститутів. Як правильно визначають А.Пехник та А.Кройтор «реформа місцевого самоврядування передусім повинна забезпечити створення раціональної, а отже, і ефективної, моделі регіональної організації влади на засадах децентралізації повноважень та відповідальності в розробленні й ухваленні управлінських рішень на місцях з урахуванням місцевих особливостей. Крім того, реформа має забезпечити формування економічно спроможних територіальних громад, що, безумовно, вплине на зміну регіональної політики» ${ }^{1}$

Таким чином, ефективність місцевого самоврядування представляється комплексною проблемою, яка включає питання прийняття управлінських рішень, політичної автономії i громадської участі.

Висновки. Підвищення ефективності місцевого самоврядування, формування позитивного образу і досягнення високої оцінки діяльності органів місцевого самоврядування $є$ взаємопов' язаними завданнями. Рішення цих завдань неможливе виключно за рахунок посилення державного контролю та регламентації сфери надання публічних послуг. Оскільки місцеве самоврядування передбачає збіг суб'єкта та об'єкта управління, тобто участь місцевого населення у вирішенні всіх що їх стосуються, то оцінка його ефективності насамперед залежить від ступеня участі громадян у вирішенні завдань місцевого значення.

Задоволеність діяльністю органів місцевого самоврядування може виражатися в різних оцінках. Держава може задати такі критерії, які формально будуть показувати позитивну динаміку, але якісні зміни будуть помітні лише тоді, коли важливим критерієм оцінки ефективності даного інституту публічної влади стане ступінь активності участі громадян у вирішенні питань місцевого значення. В даному випадку підвищення ефективності місцевої влади в більшій мірі буде результатом розвитку місцевої демократії та місцевої автономії- базових характеристик місцевого самоврядування. Очевидно, що в нових умовах оцінка ефективності місцевого самоврядування потребує нових критеріїв, з яких головними стають громадянське участь та ступінь громадянської активності.

\section{References:}

1. Atamanchuk, G. (2000). Gosudarstvennoye upravleniye (organizatsionno-funktsionalnyye voprosy) [Public administration (organizational and functional issues)]. Moscow. [in Russian].

2. Babinova, O. (2007). Kryteriyi otsinky efektyvnosti diyalnosti orhaniv mistsevoho samovryaduvannya: svitovyy dosvid ta Ukrayina [Criteria for evaluating the effectiveness of local governments: world experience and Ukraine]. Rehionalna polityka ta mistseve samovryaduvannya. Stratehichni priorytety [Regional policy and local selfgovernment. Strategic priorities], 2 (3), 79-80. [in Ukrainian].

3. Havrylyshyn, B. (2009). Do efektyvnykh suspilstv: Dorohovkazy v maybutnye: dopovid Rymskomu Klubovi [Towards Effective Societies: Roadmaps for the Future: A Report to the Club of Rome]. Kyiv. [in Ukrainian].

4. Drucker, P. (2000). Management tasks in the XXI century [Zadachi menedzhmenta v XXI veke]. Moscow. [in Russian].

5. Khol, J. (1975). Effektivnost upravlencheskikh resheniy [The effectiveness of management decisions]. Moscow. [in Russian].

6. Lesechko, M. (2002). Osnovy systemnoho pidkhodu: teoriya, metodolohiya, praktyka [Fundamentals of systems approach: theory, methodology, practice]. Lviv. [in Ukrainian].

7. Melnyk, A. (2009). Derzhavne upravlinnya [Public administration]. Kyiv. [in Ukrainian].

8. Milner, B. (2000). Teoriya organizatsii [Organization theory]. Moscow. [in Russian].

9. Nyzhnyk, N. (2000). Do problemy efektyvnosti derzhavnoho upravlinnya v Ukrayini [o the problem of efficiency of public administration in Ukraine]. Pidvyshchennya efektyvnosti derzhavnoho upravlinnya: stan, perspektyvy ta

\footnotetext{
${ }^{1}$ Пехник, А., Кройтор, А. (2020). Реформи місцевого самоврядування та територіальної організації влади в Україні в контексті становлення громадянського суспільства. Актуальні проблеми політики, 65, 69.
} 
svitovyy dosvid: zbirnyk naukovykh prats [Improving the efficiency of public administration: status, prospects and world experience: a collection of scientific papers] Kyiv. [in Ukrainian].

10. Pekhnyk A., Kroytor A. (2020). Reformy mistsevoho samovryaduvannya ta terytorialnoyi orhanizatsiyi vlady v Ukrayini v konteksti stanovlennya hromadyanskoho suspilstva [Reforms of local self-government and territorial organization of power in Ukraine in the context of the formation of civil society]. Aktualni problemy polityky [Current policy issues], 65, 69. [in Ukrainian].

11. Rozputenko, I., Pukhkal, O., Braychenko, O. (2005). Efektyvnist derzhavnoho upravlinnya ta upravlinskykh kadriv $v$ umovakh zmin [Efficiency of public administration and managerial staff in the conditions of changes]. Kyiv. [in Ukrainian].

12. Savas, E. (1972). Privatizatsiya - klyuch k rynku [Privatization is the key to the market]. Moscow. [in Russian].

13. Saymon, H. (2001). Administratyvna povedinka: doslidzhennya protsesiv pryynyattya rishen $v$ orhanizatsiyakh, shcho vykonuyut administratyvni funktsiyi [Administrative behavior: a study of decision-making processes in organizations that perform administrative functions]. Kyiv. [in Ukrainian].

14. 14. Tsvetkov, V. (1996). Derzhavne upravlinnya: osnovni faktory efektyvnosti (polityko-pravovyy aspekt) [Public administration: the main factors of efficiency (political and legal aspect)]. Kharkiv. [in Ukrainian].

15. Chemerys, A. (2001). Diyevist orhaniv derzhavnoho upravlinnya ta orhaniv mistsevoho samovryaduvannya [Effectiveness of public administration bodies and local self-government bodies]. Visnyk derzhavnoyi sluzhby Ukrayiny [Bulletin of the Civil Service of Ukraine], 1, 54. [in Ukrainian]. 